\title{
OPTIMISATION OF PRODUCTION, FREEZE-DRYING AND STORAGE OF Pseudomonas fluorescens BTP1
}

\author{
MPUTU K.J. ${ }^{1,2 *}$ AND THONART P. ${ }^{1}$ \\ Gembloux Belgium. \\ 2Department of Chemistry, Faculty of Sciences, University of Kinshasa, BP $190 \mathrm{Kin}$ XI, DR Congo. \\ *Corresponding Author: Email- kanyinda2004@gmail.com
}

${ }^{1}$ Walloon Center for Industrial Biology (CWBI), Bio-Industry Unit, Gembloux Agro-Bio Tech, University of Liege, Passage des Déportés, 2-5030

Received: January 12, 2013; Accepted: March 04, 2013

\begin{abstract}
The optimisation of production and freeze-drying of $P$. fluorescens used as a bio-control agent was investigated. $P$. fluorescens BTP1 was produced in a bioreactor with different against-pressure value ( 0.1 and 0.3 bar for bioreactor 1 and 2 respectively) and cells were harvested during the stationary phase (2Hrs. and $4 \mathrm{Hrs}$. for bioreactor 1 and 2 respectively). A mixture of protective compounds were tested for freeze-drying, and the highest result was found for glycerol and maltodextrine (26\%) followed by glycerol, maltodextrine and ascorbic acid $(18.9 \%)$ and glycerol with ascorbic acid $(8.5 \%)$. We observed that the survival rate is better at $4^{\circ} \mathrm{C}$ than at room temperature and those powders with protective compounds have a survival rate greater than the powder without protective compounds during storage.
\end{abstract}

Keywords- Bioreactor, freeze-drying, optimisation, protective compound, water activity

Citation: Mputu K.J. and Thonart P. (2013) Optimisation of Production, Freeze-drying and Storage of Pseudomonas fluorescens BTP1. International Journal of Microbiology Research, ISSN: 0975-5276 \& E-ISSN: 0975-9174, Volume 5, Issue 2, pp.-371-374. DOI : 10.9735/09755276.5.2.371-374.

Copyright: Copyright@2013 Mputu K.J. and Thonart P. This is an open-access article distributed under the terms of the Creative Commons Attribution License, which permits unrestricted use, distribution and reproduction in any medium, provided the original author and source are credited.

\section{Introduction}

Freeze-drying is a commonly used method to preserve bacteria in research as well as in industry. Freeze-drying is a technique suitable for production of concentrated bacterial cultures with the advantage that the dried material can be stored at ambient temperature and easily transported [1-5]. However, freeze-drying brings about undesirable side effects, such as modifications in the physical state of membrane lipids and altered proteins, causing the loss of cell viability during the process as well as during subsequent storage [6]. Lipid oxidation of membrane cells was deemed responsible for cell death during freeze-drying and during storage [6-8]. The knowledge and control of some parameters in the production of $P$. fluorescens in bioreactors allows cells to survive during freezedrying [9]. Different physiological states are obtained by harvesting the cells in different growth phases or by transiently creating nonoptimal growth conditions. Freeze-drying survival is commonly found to be higher for stationary-phase cells than for exponentially growing cells. The stationary phase, induced by carbon starvation, triggers a general stress response, which involves induction of a wide range of stress proteins $[1,10]$. The conditioning freeze-dried powder under vacuum in packaging light-tight and water vapor, increases the storage time [11]. As well as protective compounds, growing conditions also influence the resulting viability after freezedrying [12]. Another important parameter affecting the stability of the product is the value of the water activity $\left(a_{w}\right)$ [13]. This value depends on parameters of the drying process (e.g. time) and can be adjusted to a certain degree after freeze-drying. At high $a_{w}$ values, the dry cell can be destroyed because solutes can diffuse in water and therefore damage the cell by an osmotic effect [11]

The aim of this study was to investigate the effect of different growth conditions, different protective compounds on $P$. fluorescens BTP1 and influence of the storage temperature.

\section{Materials and Methods Organisms and Growth}

$P$. fluorescens BTP1 used in our study was from the Walloon Center of Industrial Biology laboratory (CWBI) [14]. P. fluorescens was cultivated in 863 medium at $30^{\circ} \mathrm{C}$. Pre-cultures of $100 \mathrm{ml}$ were grown for $24 \mathrm{Hrs}$. in an Erlenmeyer flask at $150 \mathrm{rpm}$ in a rotary shaker. The pre-culture was inoculated into 5-L Erlenmeyer flasks containing $3 \mathrm{~L}$ of 863 medium, and grown for $24 \mathrm{Hrs}$. at $30^{\circ} \mathrm{C}$ and 150 $\mathrm{rpm}$ in a rotary shaker before bioreactor inoculation. The bioreactor (Biolafitte, France) had a working volume of $250 \mathrm{~L}$ and was equipped with an electrical heating jacket and temperature sensor. Aeration was carried out by sparging with air at an initial gas flow of $1 \mathrm{vvm}$ [15]. Air saturation was controlled by automatic regulation of the stirring speed, which was in the range 100-150 rpm, depending on the oxygen consumption rate. The $\mathrm{pH}$ was maintained at $\sim 7$ by addition of $14 \% \mathrm{KOH}$ solution. Cell growth was monitored as optical density (OD) at $540 \mathrm{~nm}$ with a spectrophotometer (V-1200) and the cultivation time was 16 hours. Cells were harvested by centrifugation $\left(7000 \mathrm{xg}, 20\right.$ minutes, $\left.4^{\circ} \mathrm{C}\right)$.

\section{Preparation of Freeze-Drying}

Cells were harvested in the stationary phase of growth by centrifugation $\left(7000 \mathrm{xg}, 20\right.$ minutes, $\left.4^{\circ} \mathrm{C}\right)$. After centrifugation, pellets were 
divided into three parts: two with protective compounds (1 or $2 \% \mathrm{w} /$ w glycerol, 5 or $10 \%$ maltodextrine and $0.1 \%$ of ascorbic acid) and one without protective compounds [2,3]. Protective solution where sterilised at $121^{\circ} \mathrm{C}$ for 10 minutes before mixing. Then samples were placed in the freezer for $24 \mathrm{Hrs}$. and the frozen samples were freeze-dried for $72 \mathrm{Hrs}$. in a freeze-drier (LOUW KOELTECHNIEK BVBA) with a standard program. The time for primary drying was about $6 \mathrm{~h}$, the condenser temperature $-45^{\circ} \mathrm{C}$ and the final sample temperature was $25^{\circ} \mathrm{C}$ by increasing the temperature gradually from $-45^{\circ} \mathrm{C}$ to $25^{\circ} \mathrm{C}$ at 0.9 mbar pressure $[16,17]$. For storage tests, samples were sealed under vacuum in aluminium sachets and stored at 4 or $20^{\circ} \mathrm{C}$

\section{Measurement of Cultivability and Water Activity $\left(a_{w}\right)$}

The number of viable cells during growth, before freezing, after freeze-drying and during storage was determined as colony forming units (CFU). Samples were rehydrated by addition of $9 \mathrm{ml}$ peptone water and $100 \mu \mathrm{l}$ was thereafter plated on plate counts agar (PCA). After serial dilutions in peptone water, cells were plated onto solid 868 agar and incubated at $30^{\circ} \mathrm{C}$ for $24 \mathrm{Hrs}$. The number of colonies was counted after $24 \mathrm{Hrs}$. incubation and survival rate was expressed as the ratio of colony-forming units per $\mathrm{mg}$ or $\mathrm{ml}$ after freeze-drying $\left(\mathrm{N}_{\mathrm{f}}\right)$ and before freeze-drying $\left(\mathrm{N}_{0}\right)$. Viability $(\%)=\left(\mathrm{N}_{\mathrm{f}}\right)$ $\left.\mathrm{N}_{0}\right) \times 100$. Water activity was measured by a water activity meter $\mathrm{Gbx}$, each result was the geometrical mean of at least three counts [2].

\section{Statistical Analysis}

Data from three replicates were analysed by using analysis of variance to determine if significant difference $(P \leq 0.05)$ existed between mean values (origin 6.1 system function).

\section{Results}

\section{Bioreactor Growth}

In this work, two bioreactors were initiated and monitoring in the same operating conditions of $\mathrm{pH}$, temperature, agitation and volume content. The only major differences were the time to harvest of cell biomass and against pressure. In the first bioreactor, against pressure was 0.1 bar while in the second bioreactor, this against pressure was 0.3 bar [Table-1]. Cell biomass in the first bioreactor was harvested $4 \mathrm{Hrs}$. after the stationary phase while in the second bioreactor; cell biomass was harvested $2 \mathrm{Hrs}$. after beginning of the stationary phase. The inoculums conditions were also identical in terms of growth time, temperature of growth and agitation. The consumption of $\mathrm{KOH}$ and oxygen during cell growth, optical density evolution and viability during growth is shown in [Fig-1] for the first bioreactor and in [Fig-2] for the second bioreactor.

Table 1- Various parameters of the production in bioreactor of Pseudomonas fluorescens

\begin{tabular}{|cccccccccc|}
\hline \multicolumn{1}{|c|}{ Bioreactor 1 } & \multicolumn{4}{c|}{ Bioreactor 2 } \\
\hline $\mathrm{pO}_{2}$ & $\mathrm{pH}$ & $\mathrm{T}\left({ }^{\circ} \mathrm{C}\right)$ & ${ }^{*} \mathrm{pO}_{2}$ & Yield & $\mathrm{pO}_{2}$ & $\mathrm{pH}$ & $\mathrm{T}\left({ }^{\circ} \mathrm{C}\right)$ & ${ }^{*} \mathrm{pO}_{2}$ & Yield \\
$1 \mathrm{vvm}$ & $7.0 \pm 0.3$ & $30 \pm 2$ & $0.1 \mathrm{bar}$ & $75 \%$ & $1 \mathrm{vvm}$ & $7.0 \pm 0.3$ & $30 \pm 2$ & $0.3 \mathrm{bar}$ & $88 \%$ \\
\hline
\end{tabular}

\section{Freeze-Drying}

When $P$. fluorescens was freeze-dried without protective compounds, the viability dropped to $1 \%$ for the powder with the first bioreactor and $2 \%$ for the second bioreactor. Cells were freezedried with different protective compounds, and survival rate, dry matter and water activity after freeze-drying were determined [Table -2]. For the first bioreactor, the pellet was divided into three parts:
P1 with $2 \%$ glycerol, $5 \%$ maltodextrine and $0.2 \%$ ascorbic acid; P2 with $2 \%$ glycerol and $0.2 \%$ ascorbic acid; and P3 without protective compounds. The final water activity was $0.27 \pm 0.03,0.30 \pm 0.01$ and $0.28 \pm 0.02$ respectively. The dry matter was about $92.8 \pm 0.6$ for $\mathrm{P} 1$, $84.2 \pm 0.1$ for $P 2$ and $95.5 \pm 0.1$ for $P 3$. The survival rate after freezedrying was $18.9 \%$ for $\mathrm{P} 1,8.5$ for $\mathrm{P} 2$ and $1.0 \%$ for P3. In the second bioreactor, the pellet was divided into two parts: $\mathrm{S} 1$ with $1 \%$ of glycerol, $10 \%$ of maltodextrine; and S2 without protective compounds. The final water activity was $0.24 \pm 0.02$ for $S 1$ and $0.23 \pm 0.02$ for S2. The dry matter was about $93.4 \pm 0.2$ and $95.0 \pm 0.2$ for S1 and S2 respectively. The survival rate after freeze-drying was $26 \%$ for S1and $2 \%$ for S2. Protective compounds alone or mixtures improved viability of cells during freeze-drying. The highest survival rate was obtained with the $\mathrm{S} 1$ sample of the second bioreactor.

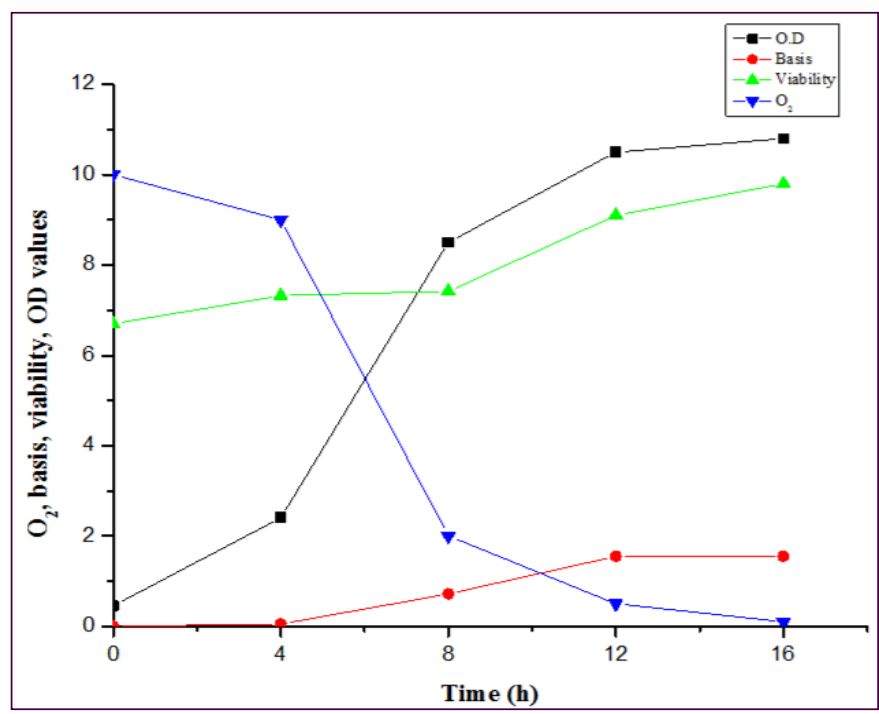

Fig. 1- Evolution of the number of cells per ml, the optical density, oxygen and base $(\mathrm{KOH})$ in the growth of $P$. fluorescens BTP 1 in $300 \mathrm{~L}$ bioreactor 1 .

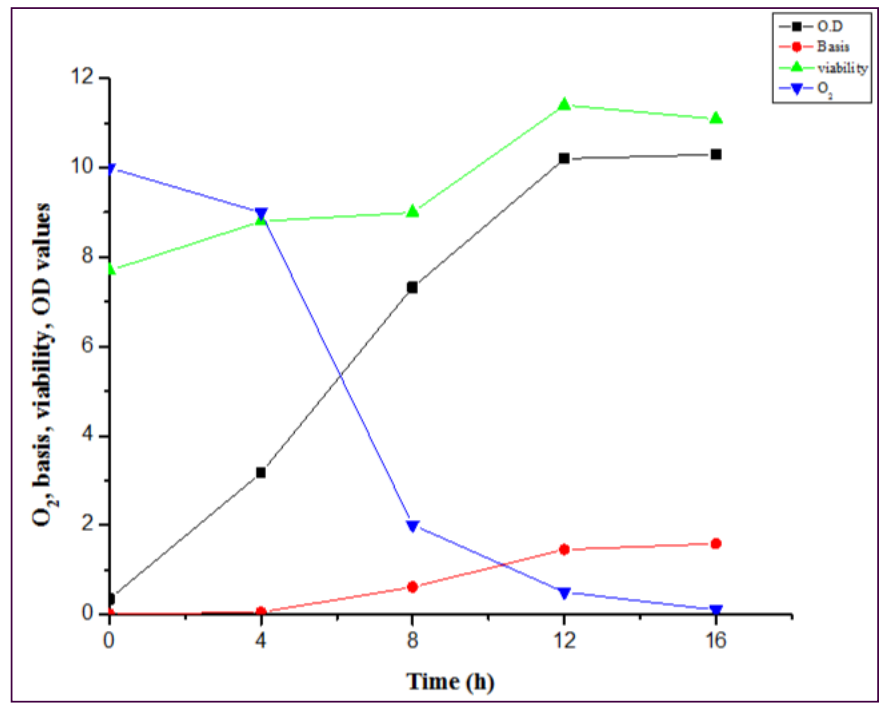

Fig. 2- Evolution of the number of cells per ml, the optical density, oxygen and base $(\mathrm{KOH})$ in the growth of $P$. fluorescens BTP 1 in $300 \mathrm{~L}$ bioreactor 2 .

\section{Storage Test}

Freeze-dried cultures were stored in portion-size $(3 \pm 0.2 \mathrm{~g})$ in aluminum packets under vacuum and stored at $4^{\circ} \mathrm{C}$ and at room temper- 
ature for 90 days. The water activity, an important factor in the preservation of freeze-dried powders, was measured before vacuum packaging of powders [Table-2]. The dry matter was measured directly after freeze-drying [Table-2]. [Fig-3] and [Fig-4] show the evolution of survival rates for powders obtained in the first bioreactor and the results for survival of bioreactor 2 are show in [Fig-5] and [Fig-6]. These results show that the survival rate is better at $4^{\circ}$ $C$ than at room temperature and that powders with protective compounds ( $\mathrm{P} 1$ and $\mathrm{P} 2$ ) have a survival rate greater than the powder without protective compounds $(\mathrm{P} 3)$ during storage. For the second bioreactor, the survival rate for the different powders (S1 and S2) was better at $4^{\circ} \mathrm{C}$ than at room temperature. The powder with protective compounds (S1) had a greater survival rate than the powder without protective compounds during storage at $4^{\circ} \mathrm{C}$ and at room temperature.

Table 2- Percentage survival, water activity and dry matter of different combinations of protective compounds after freeze-drying.

\begin{tabular}{|lccclccc|}
\hline \multicolumn{4}{c}{ Bioreactor 1 } & \multicolumn{4}{c}{ Bioreactor 1 } \\
Sample & D.M & $a_{w}$ & survival & Sample & D.M & $a_{w}$ & survival \\
P1 & $92.8 \pm 0.6$ & $0.27 \pm 0.03$ & $18.90 \%$ & S1 & $93.4 \pm 0.2$ & $0.23 \pm 0.02$ & $26 \%$ \\
P2 & $84.8 \pm 0.1$ & $0.26 \pm 0.01$ & $8.50 \%$ & S2 & $95.0 \pm 0.2$ & $0.29 \pm 0.02$ & $2 \%$ \\
P3 & $95.5 \pm 0.1$ & $0.33 \pm 0.02$ & $1.00 \%$ & - & - & - & - \\
\hline
\end{tabular}

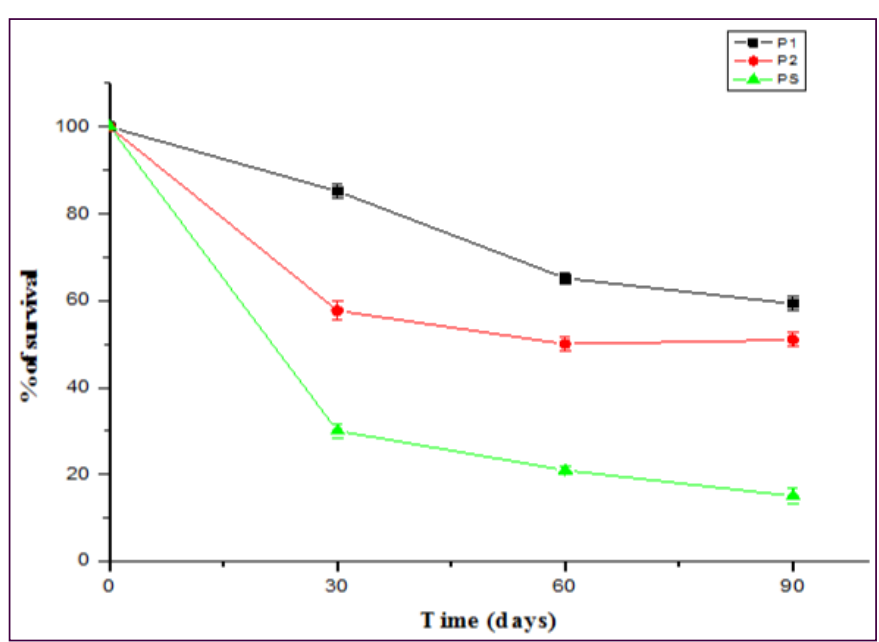

Fig. 3- Loss in survival of freeze-dried $P$. fluorescens BTP during storage at $4^{\circ} \mathrm{C}$ under vacuum with and without protectors.

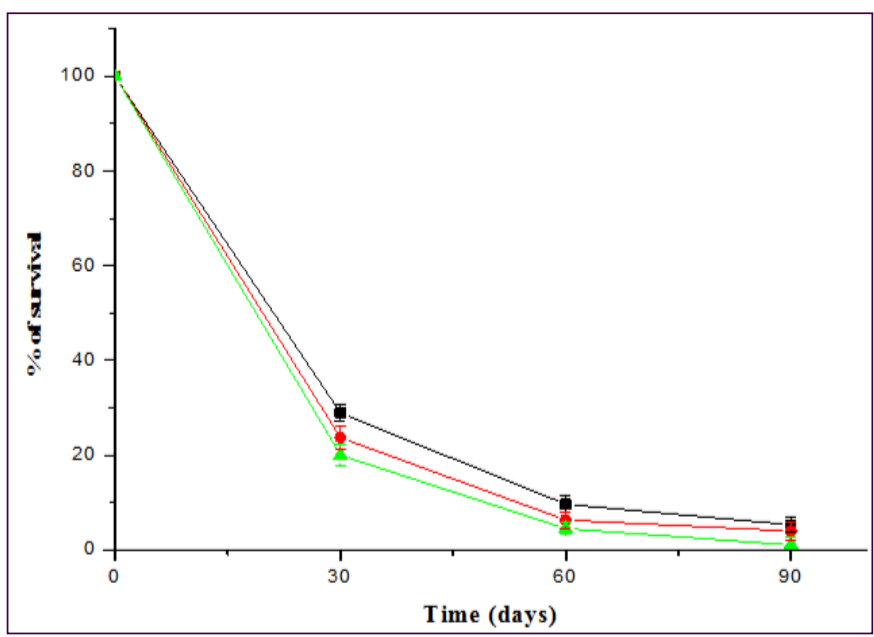

Fig. 4- Loss in survival of freeze-dried Pseudomonas fluorescens BTP during storage at room temperature under vacuum with and without protectors

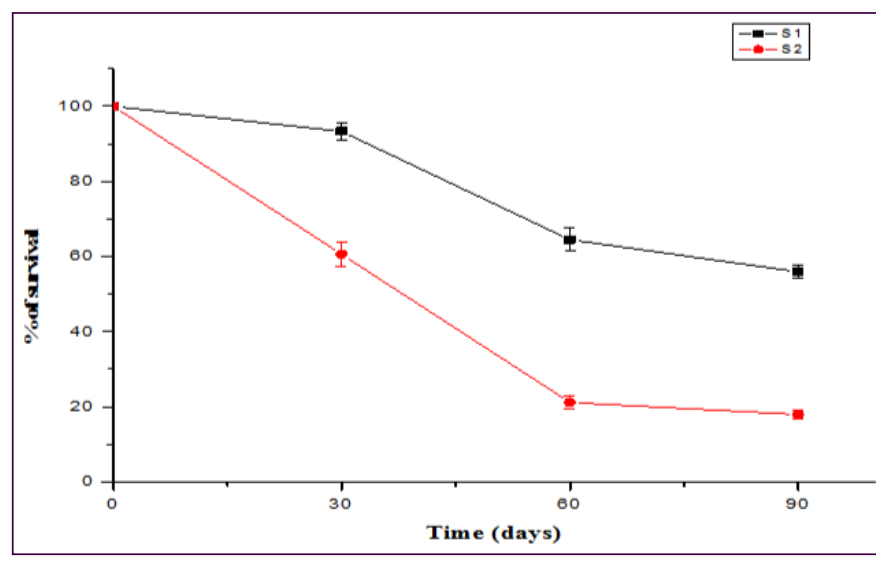

Fig. 5- Loss in survival of freeze-dried $P$. fluorescens BTP during storage at $4^{\circ} \mathrm{C}$ under vacuum with and without protectors

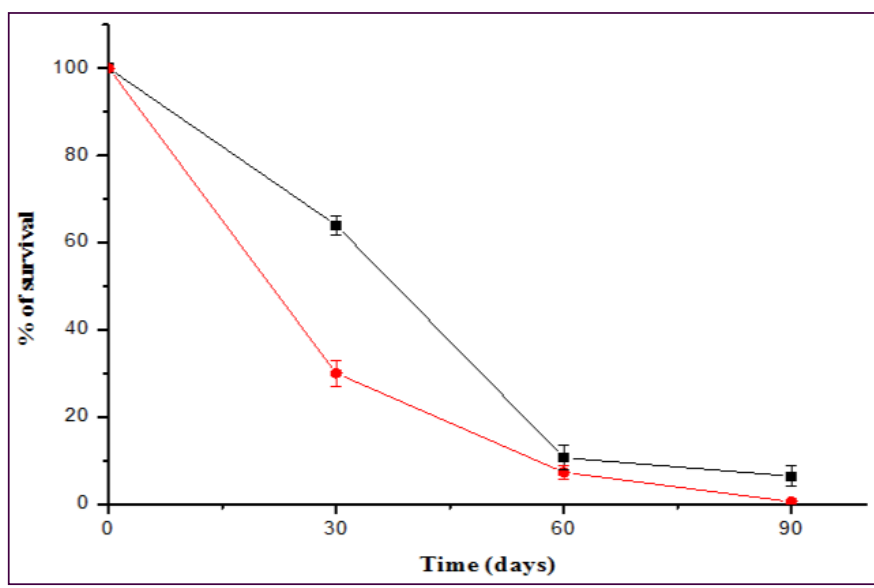

Fig. 6- Loss in survival of freeze-dried Pseudomonas fluorescens BTP during storage at room temperature under vacuum with and without protectors

\section{Discussion}

The inoculums of our two bioreactors were performed under the same conditions (culture time, temperature, agitation and composition of the culture medium). After $24 \mathrm{Hrs}$. of culture, optical densities $\left(O D_{540 \mathrm{~nm}}\right)$ of precultures were respectively 5.4 and 6.3 for the first and second bioreactor [18]. The second inoculum was carried out 3 weeks after the first. This bioreactor was inoculated and the following parameters were monitored to improve production: temperature maintained at $30^{\circ} \mathrm{C}, \mathrm{pH}$ maintained at $\sim 7$ by adding $14 \% \mathrm{KOH}$ solution. The only major difference between the two bioreactors was the pressure against $(0.1$ bar in the first bioreactor and 0.3 bar in the second) [Table-1]. By comparing the two bioreactors we observe that the consumption of $\mathrm{KOH}$ to maintain $\mathrm{pH}$ at $\sim 7$ was almost identical during production (about $1.5 \mathrm{~L}$ ). It was the same for the oxygen consumption and the optical density increasing. The only difference was observed in bacterial growth: in the first bioreactor, the stationary phase started after $18 \mathrm{Hrs}$. of culture and the cell concentration at the end was $6.3 \times 10^{9} \mathrm{CFU} / \mathrm{ml}$ [Fig-3], while in the second bioreactor, the stationary phase occured after only $12 \mathrm{Hrs}$. culture and the cell concentration at the end was $1.3 \times 10^{11} \mathrm{CFU} / \mathrm{ml}$ [Fig-3]. The second bioreactor considerably reduced culture time and increased efficiency of production of $P$. fluorescens BTP1.

The freezing step is part of the freeze-drying procedure [19]. Samples were frozen for 24 hours in a freezer before freeze-drying and the time to freeze-drying of our samples was 72 hours in order to 
have powder with a higher dry matter and a low water activity. The pellet was divided into two parts, i.e. with and without protective compounds. Our results show that powders with protective compounds have a higher survival rate than powders without protective compounds. The survival rate for P1 (powder with 2\% glycerol, $5 \%$ maltodextrine and $0.2 \%$ ascorbic acid) was $18.9 \%, 8.5 \%$ for P2 (powder with $2 \%$ glycerol and $0.2 \%$ ascorbic acid) and $26 \%$ for $\mathrm{S} 1$ (powder with $1 \%$ glycerol and $10 \%$ maltodextrine). Powders without protective compounds (P3, S2) each had a survival rate of 1 to $2 \%$ after freeze-drying [Table-2]. Similar results were found previously $[1,3,6,20]$. By comparing powders with protective compounds, we observe that $\mathrm{S} 1$ gives a higher survival rate and dry matter than P1 and $\mathrm{P} 2$. The difference in survival rate of the different powders can be explained by the concentration of protective compounds and by the cell concentration before freeze-drying $\left(1.6 \times 10^{10} \mathrm{CFU} / \mathrm{g}\right.$ for the first bioreactor and $1.03 \times 10^{11} \mathrm{CFU} / \mathrm{g}$ for the second) [1]. The initial water activity was lower than the water activities chosen for Pseudomonas storage [16]. The European Patent No. EP 1234019 B1 published in august 28, 2002 reports that the water activity reflects the degree of freedom of the water in the product concerned and has a strong impact on the stability and preservation during storage of this product.

After freeze-drying, powders with and without protective compounds were sealed in aluminum sachets under vacuum and stored at 4 or at room temperature. The survival rates of powders without protective compounds $\mathrm{P} 3$ and S2 decrease during storage at 4 or at room temperature. But this decrease is most pronounced at room temperature. Example for $\mathrm{P} 3$ survival rate is $15 \%$ at $4^{\circ} \mathrm{C}$ and $1.1 \%$ at room temperature and for $\mathrm{S} 2$ survival rate at $4^{\circ} \mathrm{C}$ is $18 \%$ and $1 \%$ at room temperature. The highest survival rates were observed at $4^{\circ} \mathrm{C} 59 \%$ for $\mathrm{P} 1,51 \%$ and $56 \%$ for $\mathrm{P} 2$ and $\mathrm{S} 3$ respectively. The international patent WO 03/018778 published august 30, 2001 confirm that more the storage temperature is low, best is storage the freeze-dried powders; and conditioning freeze-dried powder under vacuum in light-tight packaging and water vapour increases the storage time. Our results show that glycerol and maltodextrine have a strong protective effect upon the survival Pseudomonas during freezedrying, and similar results were found in our previous study $[3,21]$. However, industrially used bacteria, such as lactic acid bacteria, typically show survival values above $50 \%$ when dried in the presence of a protective compound [10] and above $1 \%$ when dried in the absence of protective compounds [22]. The survival values of $26 \%$ in the presence of a protective compound and below $2 \%$ in its absence show that $P$. fluorescens is rather sensitive to freezedrying; similar results were found for $P$. chlororaphis [1].

\section{Conclusion}

In conclusion, the present study shows that carbon starvation, growth time, freeze-drying, protective compounds and the initial cell concentration contributes to enhanced freeze-drying survival and if one of them is suboptimal the survival decreases. It would also be important to study the stability of freeze-dried $P$. fluorescens bacteria. These findings are necessary for the industrial development of the starter culture formulation.

\section{Acknowledgements}

The authors would like to acknowledge Walloon Region (Consalim) for assistant aids. We thank all the technical's personals of CWBI (Centre Wallon de Biologie Industrielle). We also express our gratitude to Wallonie-Bruxelles International for its financial assistance.

\section{References}

[1] Palmfeldt J., Radström P. and Hahn-Hägerdal B. (2003) Cryobiol., 47, 21-29.

[2] Coulibaly I., Yao A.A., Lognay G., Fauconnier M.L. and Thonart P. (2009) Appl. Biochem. and Biotech., 157, 70-84.

[3] Mputu Kanyinda J-N., Pierart C., Weekers F., Destain J. and Thonart P. (2012) Int. J of Biotech. and Biochem., 8, 17-26.

[4] Morgan C.A., Herman N., White P.A. and Vesey G. (2006) J. of Microbiol. Meth., 66, 183-193.

[5] Louis P., Trüper H.G. and Galinski E.A. (1994) Appl. Microbiol. and Biotech., 41, 684-688.

[6] Mputu Kanyinda J-N., Pierart C., Weekers F., Delvigne F., Destain J., Wathelet J-P. and Thonart P. (2012) Int. J. of Biotech. and Biochem., 8, 245-258.

[7] Garait B., Couturier K., Servais S., Letexier D., Perrin D., Batandier C., Rouanet J-L., Sibille B., Rey B., Leverve X. and Favier R. (2005) Free Radic. Biol. and Med., 29, 1249-1261.

[8] Nanasombat S. and Sriwong N. (2007) Sc. Tech. J., 7, 61-67.

[9] Slininger P.J., Van Cauwenberge J.E., Bothast R.J., Weller D.M., Thomashow L.S. and Cook R.J. (1996) Appl. Microbiol. and Biotechn., 45, 391-398.

[10]Palmfeldt J. and Hahn-Hagerdal (2000) Int. J. of Food Microbiol., 55, 235-238.

[11]Béal C., Mihoub F., Marin M. and Corrieu C. (2001) INRA (Ed.), European Office Patent, France.

[12]Abadias M., Benabarre A., Teixido' J., Usall U. and Vinas I. (2001) Int. J. of Food Microbiol., 65, 173-182.

[13]Coulibaly I., Dubois-Dauphin R., Danthine S., Majad L., Mejoub T., Destain J., Béra F., Wathelet J-P., Thonart P. (2011) Biotechnol. Agro. Soc. and Environ., 15, 287-299.

[14]Ongena M., Daayf F., Jacques P., Thonart P., Benhamou N., Paulitz, T.C., Cornélis P., Koedam N. and Bélanger R.R. (1999) Plant Pathol., 48, 66-76.

[15]Yao A.A., Wathelet B. and Thonart P. (2009) J. of Microbiol. and Biotechnol., 19, 810-817.

[16]Jørgensen F., Nybroe O. and Knøchel S. (1994) J. of Appl. Microbiol., 77, 340-347.

[17]Yao A.A., Djè K.M. and Thonart P. (2010) The Open Biotechnol. J., 4, 8-13.

[18]Dutta J.R., Dutta P.K. and Banerjee R. (2004) Process Biochem., 39, 2193-2198.

[19]Perry S.F. (1998) Molecul. Biotechn., 9, 59-64.

[20]Saarela M., Virkajärvi I., Alakomi H-L., Mattila-Sandholm T., Vaari A., Suomalainen T. and Mättö J. (2005) J. of Appl. Microbiol., 99, 1330-1339.

[21]Stephan D., Bisutti I.L., Matos da Silva A.-P. and Covi J. (2007) Biol. Control of Fungal and Bacterial Plant Path., 30, 511-515.

[22]Leslie S.B., Israeli E., Lighthart B., Crowe J.H. and Crowe L.M. (1995) Appl. and Env. Microbio., 61, 3592-3597. 